\title{
Editorial
}

\section{Editorial Revista Ensaio 46}

A Revista ENSAIO é um veículo de comunicação permanente entre a Fundação Cesgranrio e a comunidade acadêmica.

Em sua trajetória de 11 anos ininterruptos vem socializando o pensamento de renomados educadores que, com o registro de suas reflexões e experiências, enriquecem suas páginas e multiplicam seu saber.

Na era da informação e da comunicação, em que o conhecimento constitui um instrumento de inestimável valor, a Revista Ensaio assume papel de destaque pela contribuição acadêmica de alto nível que propicia, por meio dos artigos e estudos que publica.

Neste número, oferecemos aos nossos leitores o artigo Desseriação Escolar: alternativa para o sucesso, de Cândido Alberto Gomes, originado de uma pesquisa resultante de 62 outras, nacionais, com diferentes enfoques, objetivando efetuar um balanço das experiências do Ensino Fundamental do Brasil, nos últimos 15 anos, buscando responder se tais experiências têm contribuído para melhorar o desempenho dos alunos ou se, ao contrário, para a queda do aproveitamento discente.

No artigo $O$ significado das tecnologias de informação para educadores, de Christina Marília Teixeira da Silva e Nyrma Souza Nunes de Azevedo, as autoras descrevem o resultado de uma pesquisa de natureza quantiqualitativa, com referência às percepções de docentes com relação às tecnologias de informação, em especial , o Computador e a Internet.

Crítica Pedagógica aos Sistemas Educativos Ocidentais, da autoria do Professor José Maria Quintana Cabanas, no qual pretende mostrar a necessidade de uma visão crítica da educação e das diferentes reformas ocorridas na Espanha. Enfoca fenômenos que vêm interferindo na educação como a violência escolar.Aborda os problemas, enfatizando que a educação atual sofre o grave entrave da falta de controle e destaca o fracasso escolar como agravante das principais dificuldades do sistema educativo. 
Na sessão Página Aberta, no texto Os desafios de fazer uma avaliação útil, Michael Quinn Patton informa que a avaliação, como profissão, vem estudando meios da utilização das avaliações. Nele são apresentadas algumas lições aprendidas como importantes para que as avaliações sejam realmente úteis.

A Pesquisa em Síntese apresenta Projeto Político-Pedagógico: utopia ou realidade? na qual João Malheiro divulga o resultado de um estudo realizado em algumas escolas do Município do Rio de Janeiro, no sentido de investigar como essas escolas estavam construindo seus Projetos PolíticoPedagógicos, instrumentos de planejamento que tendem a facilitar a conquista da autonomia na gestão escolar.

A sessão Informes e Participações traz Questões éticas da prática da avaliação no contexto político brasileiro, trabalho por mim elaborado juntamente com as professoras Thereza Penna Firme e Ana Carolina Letichevisck, apresentado na 18th Annual Conference of the American Evaluation Association, e que avalia um conflito freqüentemente encontrado por profissionais de avaliação, atuantes no contexto brasileiro, bem como suas respectivas implicações para o processo avaliativo.

Ao passar às mãos dos educadores o presente número, o fazemos com elevado senso de responsabilidade e alto grau de satisfação, diante do compromisso assumido pela Fundação Cesgranrio, ao conceber e editar a Revista Ensaio - o de divulgar o melhor e o mais atual pensamento de educadores brasileiros e estrangeiros.

Carlos Alberto Serpa de Oliveira 